Revista Iberoamericana, Vol. LXXI, Núm. 210, Enero-Marzo 2005, 121-143

\title{
REPRESENTACION DE LA MUJER EN DOS ESCRITORES ECUATORIANOS (MEDARDO ANGEL SILVA Y JOSÉ DE LA CUADRA)
}

\author{
POR \\ Humberto E. Robles \\ Professor Emeritus, Northwestern University
}

La mujer no nace, se hace*

El nombre de Dolores Veintimilla (1829-57) resuena aún en la mitología de la historiografía literaria ecuatoriana. Todo parece indicar que su suicidio fue consecuencia de al menos dos factores. Por un lado, su desdichada relación matrimonial; por el otro, y más contundente, el acoso, acusaciones y acometidas que sufrió de parte de empecinados fiscales de normas hegemónicas intransigentes. Normas conservadoras, clericales, masculinas, que no podían tolerar la insólita voz de una mujer letrada que acusaba, que reclamaba justicia, que emitía opiniones. ${ }^{1}$

La condena a muerte de Tiburcio Lucero, amerindio acusado de parricida; los reclamos de Veintimilla por dicha sentencia, vía una hoja suelta titulada "Necrología”; y, no menos, su oposición a la pena de muerte, que ella consideraba inhumana y una usurpación: todo ello le acarreó injurias y discordias. Injurias y discordias en su mayoría provenientes del sacerdote Vicente Solano, reconocido e influyente polemista y predicador de la entonces provinciana ciudad de Cuenca, ámbito donde transcurrieron los hechos. Solano sembró y promulgó la desavenencia. No escatimó ni vituperios ni consecuencias. Veintimilla acabó marginada y demolida dentro del rígido horizonte cultural cuencano. Su muerte ontológica -la real y la metafórica- apunta, por contigüidad, a una especie de “canibalismo” simbólico, secuela de la querella entre la ignorancia y el saber, entre la intransigencia y la tolerancia, entre las empotradas convicciones de poder y una presencia femenina reclamando su espacio, su derecho y razón de ser.

La muerte de Veintimilla y las circunstancias que la dictaron resultan sintomáticas de su proscripción, del señorío y presencia de una suerte de “ogro” masculino en la sociedad

\footnotetext{
* Le agradezco a Gilda Holst el haberme recordado esta popular expresión que resuena la ya famosa que Simone de Beauvoir divulgó en Le Deuxième Sexe: "On ne naît pas femme: on le devient”. En cualquier caso, se trata, claro está, de variantes de frases de inspiración similar como: "no es noble quien nace, sino quien se hace", "o se vive como se piensa o se acaba pensando como se vive", etc. Del fondo de todas esas sentencias se rescata la oposición natura / cultura, la idea de lo significativo que es la enseñanza en la creación de la persona, en la formación del ser social. Todas aluden asimismo, por contigüidad, a la cuestión de cómo las letras o su equivalente promulgan, para bien o para mal, imágenes y conceptos de identidad.

${ }^{1}$ El novelista, ensayista y poeta G. humberto Mata (1904-88) denunció y dejó constancia de la hostilidad y sofoco que sufrió Veintimilla.
} 
ecuatoriana de la segunda mitad del siglo xix. No sorprende, por ende, que el proceso de secularización, constatado en otras latitudes, sea fundamentalmente nulo en el Ecuador de ese entonces. ${ }^{2}$ Si algo, el caso Veintimilla, con la incuestionable potestad de la Iglesia de por medio, parecería remitir a la gestación de los proyectos conservadores, por no decir reaccionarios, de Gabriel García Moreno (1821-1875), quien, sabido es, pretendió imponer una teocracia en el país durante su mandato presidencial (1861-1865). Desde una moderna y cosmopolita perspectiva histórica actual, sin embargo, el imaginario ecuatoriano rescata el caso Veintimilla a manera de alegato respecto a la usurpación de los derechos de la mujer.

Dentro de esa perspectiva habría que tener en cuenta también que hacia 1895 irrumpe en el país la figura del caudillo liberal Eloy Alfaro (1842-1912). La Revolución del 95 que éste capitaneó, lleva a cabo, según Alfredo Pareja Diezcanseco, “una transformación del alma nacional [...] todo nuestro adelanto social deriva de ella; toda la decisión ecuatoriana por las formas libres de la convivencia, toda nuestra legislación protectora del trabajo, el fervor democrático de nuestros días, posible fueron debido al triunfo del 5 de junio de 1895” (319). Secuela de lo anterior serían, para concretar, la "Ley de Matrimonio Civil y de Divorcio”, la "Ley de cultos” y el sufragio libre. ${ }^{3}$ Hacia 1930, sin embargo, y no obstante la legislación puesta en marcha por el movimiento liberal, la condición fundamental de la mujer no había variado. En la práctica, las relaciones genéricas seguían bajo el dominio del varón. Los diálogos que figuran a continuación, procedentes de dos narraciones de José de la Cuadra (1903-41) compendian ese juicio:

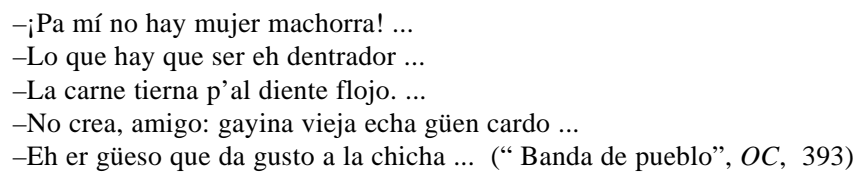

-A mí me parece muy bien, claro. ... Pero es que yo, o más mejor dicho, Terencio, que es el padrino, quiere que completen los estudios. Se van a ir pa Quito. Cuando regresen, ¡claro!, se casan con ustedes. ¡Qué mejor! De la misma sangre ...

-Déjese de vainas, tío ... ¿ ¿Pa qué mismo necesitan estudiar más? La mujer, con que sepa cocinar, a parir apriende sola ... Usté, perdonando la mala palabra, ¿le enseñó a parir a su compañera u ella hizo no más? Resuelva de una vez y no chingue, tío. (Los Sangurimas, OC, 503-04) ${ }^{4}$

${ }^{2}$ Ver Jean Franco, Plotting Women (xvii), quien suscribe que el catolicismo, al menos en México, dejó de ser hegemónico.

${ }^{3}$ Hablando de leyes, jurisprudencia y legitimación, lejos estamos en el Ecuador y, que sepamos, en América Latina de un estudio lato y metódico, similar, en ciertos sentidos nada más, al de Catharine A. MacKinnon, Toward a Feminist Theory of the State, que analice la sexualidad, la política y la ley desde una perspectiva femenina, estudio que tenga en cuenta los valores patriarcales de poder que sostienen la justicia y el nacionalismo, que sostienen, en suma, la familia y el Estado y que consideren, y esto es muy pertinente para el fenómeno latinoamericano, lo urbano y lo rural, la mujer soltera y la mujer casada, etc. Ver el capítulo titulado “Method an Politics” de MacKinnon (106-25).

${ }^{4} \mathrm{~A}$ menos que se indique lo contrario, cuando la referencia es a De la Cuadra, las siglas $O C$ remiten a: Obras completas de José de la Cuadra. 
Esos parlamentos remiten a una vox populi masculina, proverbial. Los mismos, a su vez, puntualizan una serie de convicciones y de relaciones genéricas y de potestad que exigiría un análisis detallado en cuanto a enfoque, sujeto, objeto y expropiación sexual. Baste proponer que en esos textos se manifiestan lo masculino (el poder), lo femenino (sin voluntad), la presencia de lo sexual sobre lo genérico, y las prácticas de una sociedad rural primitiva enfrentándose a vislumbres del saber y del conocimiento: de lo urbano y lo moderno. Esto último, se deduce, sería la pauta implícita a seguir en la búsqueda de una posibilidad de cambio en la situación y circunstancia histórica de la mujer. ¿¿Lo urbano y lo moderno? ¿Pero qué de la mujer rural? Independientemente de los parlamentos emitidos arriba por voces masculinas, quizás sorprendan algunos de los atributos que configuran a la mujer rural, montuvia, ¿primitiva?, según se deduce de esas u otras narraciones que suscribió el mismo De la Cuadra.

Pidiendo prestado un comentario de Carol Gilligan, expresado en otro contexto, incumbe tener en cuenta que las historias y manuales de literatura ecuatoriana, en sus informes de lectura de obras clave de la narrativa nacional del siglo xx, casi han dejado fuera la experiencia femenina. La presencia o ausencia de esa voz, las estrategias que la identifican, apenas figuran en esas lecturas. ${ }^{5}$ El objetivo aquí es entonces puntualizar la representación de la mujer en diferentes momentos de la narrativa ecuatoriana del siglo indicado. El repaso de obras características, vistas con y desde otra perspectiva, podría facilitar una novel y más amplia lectura de la historia de esa literatura, de las formas que la determinan y constituyen, y de las presuntas relaciones entre hombres y mujeres.

Las obras y autores aquí seleccionados por su carácter ilustrativo no pretenden señalar rupturas de por sí, ni tampoco alentar la trillada disputa entre los géneros. Sí trazar, a grandes rasgos, la evolución de la representación de la mujer que registra la literatura ecuatoriana del siglo pasado, tan dizque ideológicamente cargada, muy a su pesar quizás, de atributos patriarcales. Varias perspectivas sería de tener en cuenta: 1) la perspectiva histórica actual: urbana, cosmopolita; 2) el desajuste cultural y las ideas fuera de lugar: el modernismo; 3) la presencia urbana de un feminismo burgués en embrión: la literatura rosa o galante; 4) denuncia, protesta y antropología: la clase social y la geografía en la imagen

\footnotetext{
${ }^{5}$ Vale precisar el juicio sobre los informes de lectura. La referencia es, reitero, a las historias y manuales de literatura tradicionales que están al alcance de la gran mayoría de lectores. En términos más específicos, sin embargo, la cuestión ha ido cambiando en poco más o menos los últimos veinte años. Quien más se ha preocupado por el asunto ha sido Michael H. Handelsman con estudios monográficos significativos a su haber sobre Baldomera de Alfredo Pareja Diezcanseco en Inti; "La Tigra” de José de la Cuadra en Latin American Perspectives; “La doble y única mujer" de Pablo Palacio en Chasqui; Las alcobas negras de Eugenia Viteri y La casa del Sano Placer de Alicia Yánez Cossío en Letras Femeninas. Hay también un ensayo periodístico de Miguel Donoso Pareja que distingue entre literatura sobre mujeres y literatura narrada por mujeres (Hoy, Quito, domingo 10 de julio, 1983). Varias antologías han venido recopilando las narraciones y relatos escritos por mujeres: Amazonas y artistas: un estudio de la prosa de la mujer ecuatoriana y Diez escritoras ecuatorianas y sus cuentos de Michael Handelsman. Donoso Pareja, a su vez, es el editor de Antología de narradoras ecuatorianas; Cecilia Ansaldo es la editora de Cuentan las mujeres: Antología de narradoras ecuatorianas; Adelaida López de Martínez y Gloria Da Cunha-Giabbai, editoras de Narradoras ecuatorianas de hoy. Sobre estas tres últimas antologías, Michael Handelsman ha escrito un artículo-reseña, que aparece en este mismo número.
} 
e idea de la mujer; 5) el cuestionamiento y parodia de normas e instituciones: la Vanguardia histórica; 6) el culto de valores inauténticos: el concepto de belleza, la raza, la identidad étnica; 7) la auto expresión y la autocrítica: el discurso de mujeres por mujeres. Por falta de espacio, dejamos para otra ocasión el asunto de los últimos tres apartados.

\section{DESUBICACIÓN: ADORNO Y REALIDAD}

El modernismo ecuatoriano es tardío. Medardo Angel Silva (1898-1919) es el poeta de mayor trascendencia dentro de dicha promoción. De hecho, es el más reconocido. Perteneció a la Generación Decapitada, llamada así en el Ecuador por la prematura y trágica muerte de sus miembros. Silva se suicidó. Proveniente de estratos populares, en comparación con sus compañeros de promoción, vivió la paradoja del culto de lo aristocrático y la dislocación personal. María Jesús (1919), "Breve novela campesina” que se divulgó en folletín de periódico, es de sus escritos en prosa el más pertinente aquí.

Apenas suma una veintena de páginas. La trama es sencilla. Presenta una suerte de menosprecio de corte y alabanza de aldea. El joven narrador-poeta relata su reencuentro con María Jesús, rústica campesina de apenas quince años: "una mocita morena, bien garrida ... hija de un revolucionario, un montonero bravo como un tigre y una señorita primogénita de rico hacendado. Un día murió la madre -veinticinco años, trenzas rubias, ojos tristes, frente lunar y empalidecida de una enfermedad ignorada; una noche murió el padre, luchando en la maraña palúdica, luchando contra los hombres del gobierno -o su gente- quemó la hacienda, destrozó los sembríos y mató las reses que no pudo pillar; había hecho justicia” (9).

Ese nudo narrativo no tiene mayores consecuencias, salvo el de establecer el pedigrí de María Jesús. El ser hija de un montonero y de la primogénita de trenzas rubias de un hacendado pareciera justificar la atracción que el narrador -un "exquisito de un siglo refinado y complicado”- siente hacia ella. Se mitifica a los padres, se invoca la justicia y se pasa por alto, ¿intencionalmente?, la violación que quizás oculta el engendro. Tampoco se hace hincapié en la hibridez o ¿bastardía? de la joven. No se olvida, sin embargo, un culto que ronda a distancia, el de la imagen casi canonizada de la madre del narrador: “dulce ... daba la bendición, un beso muy suave en la frente ... una mujer de serena hermosura ... tan buena con sus manos de mariposa blanca” $(26,16,22)$.

Esos factores configuran una imagen de mujer que a primera vista induce a la celebración de una suerte de pureza mariana, manto con el que, a pesar de sí, pretende adornar el narrador la orfandad y el mestizaje exótico de la erótica María Jesús: “ojos negros de mirar hondo y triste; ... tez morena de manzana madura ... pelo azuleante de lo negro ... boca sensual del progenitor audaz y bravo ... senos duros como frutos verdes, estrujados en el vestido blanco" (9). Lo sagrado y lo profano, la pureza y la lascivia, parecieran determinar la ambivalente actitud del narrador hacia María Jesús. Imposible hablar de una relación entre dos.

Entre la penumbra y la melancolía, la única voz que se oye es la del narrador. María Jesús es un mero capricho, una marioneta. Apenas habla, y cuando lo hace se expresa en la manera en que su ventrílocuo se lo permite. Reacciona. Otorga. Calla. Ignora. Su trágica 
ingenuidad campestre es vista desde el parapeto de la condescendencia cosmopolita de la razón y del conocimiento:

Junto a mí, decíame señalando una pareja de estrellas.

-Vedlas, qué unidas, esas somos nosotros ...

La pobre niña ignoraba que ninguna ley celeste las unía y que luego continuarían separadas su inalterable viaje. ...

Las estrellas gemelas, a la simple vista, se habían alejado... Pero en el agua se duplicaban millones ...

Abajo la cancagua mugía y entre sus espumas brillaban las estrellas ...

-Ven -gritó palmoteando- ...vamos a cogerlas ...

María Jesús avanzó al barranco, ... De pronto algo espantoso sucedió; el ondeante vestido blanco se prendió a una rama, el cuerpo airoso volviose a librarse del garfio ... pero vaciló y ... rodó al brillante oleaje.

Así murió María Jesús por querer mirar de cerca las estrellas. (22-23)

Así, a su vez, concluye María Jesús, salvo por un corto “Envío” que el narrador añade a manera de coda o epílogo en el que se invoca, incita y explica el porqué de su melancolía. El pasaje citado plantea una serie de alusiones, interpretaciones y conclusiones respecto a la imagen e idea de la mujer. Se promueve la tradición del príncipe y la cenicienta. Aquí, sin embargo, ese arquetipo se estanca, se aborta. ¿Se debe ello a incompatibilidades, a diferencias sociales y de educación? ¿A la condición de Otra, de incauta, de campesina y de mestiza de la protagonista? ¿Y qué se ha de deducir del hecho de que el texto de Silva apareció como folletín en El Telégrafo de Guayaquil? ¿Cuál sería la reacción de los interpelados lectores, la mayoría presuntamente mujeres, ante el accidentado y trágico fin de María Jesús? En fin, ¿qué es lo que propone y ratifica ese texto, consciente o inconscientemente, sobre las relaciones hombre-mujer y, por contigüidad, sobre relaciones culturales, de clase y de identidad?

Inevitable inducir implicaciones simbólicas de la descripción de la ya citada muerte de María Jesús. La joven ignora que “dos estrellas” no se pueden unir y que a ella le está vedado acercarse a las mismas. La relación hombre-mujer que se plantea, entonces, habría que verla tanto en un sentido literal como metafórico. Se deduce que María Jesús no es para aquél: ella carece de educación, es de otra clase social, y pertenece, además, a un menos apreciado trasfondo étnico. Vista así, la perspectiva del narrador se aproxima a lo erótico y transforma a María Jesús en deseo, en objeto sexual.

El carácter representativo de los protagonistas enarbola la relación hombre-mujer a un plano simbólico y paradójico. ¿Es que el mundo rústico de María Jesús y el del exquisito narrador están destinados a vivir separados? ¿Es que el mundo que María Jesús representa habrá de desaparecer? En la relación, lo cosmopolita y culto, que se atribuye el narrador, domina imperialmente al mundo nativo y regional que María Jesús es y representa. El mundo mágico, montuvio, de tendencia mítica, del cual ella procede-mundo de tradiciones y relatos orales, "de cuentos de aparecidos, de brujas y maleficios ... [de] vampiros descabezados y jinetes diabólicos” de “consejos ...entierros ... abusiones”, supersticiones y ensalmos, de montoneros y frailes- es visto como ingenuo, como de menor valía, como 
destinado a sucumbir (15-17). Sobrevive el mundo metropolitano, el del poder, el de la clase, el del género, conocimiento y convicciones que él narrador-poeta representa. ${ }^{6}$

María Jesús, en tanto un símbolo de comunidad cultural nativa y regional, pareciera estar destinada a perecer bajo el manto de lo planetario. Quizás por eso figura envuelta en bruma. Es una suerte de silueta fantasma, de huérfana de sí misma. La penumbra y la melancolía, a las que se inclina la ostentosa imaginación del narrador, intensifican la orfandad y bastardía de la protagonista (¿̇ son acaso las del narrador?), la anulan. La ornamentación modernista, plena de alusiones, pareciera querer borrar el referente auténtico y rústico de la costa ecuatoriana. Abundan los artefactos exóticos: chinerías y japonerías, reproducciones de mandarines en kimono; no faltan las referencias a músicas, letras, lienzos y mitologías lejanas: Grieg, Chopin, Brahms, Dukas, Debussy, John Keats, Carducci, Breardaley o Dulac, Boticelli, Rosetti, Burne Jones. No escasea la evocación de figuras legendarias: Cleopatra, Salomé, Belkiss, Lorelei; y, tampoco andan lejos libros famosos como La odisea, no hablar de divinidades llamadas Anadyomena, Tanagra, Dionysios, Afrodita. Todo se convierte en formulismo, en pretensión estética, en ostentación de cultura y saber cosmopolita, en un constante recurrir a lo "refinado", importado y “exquisito”, al adorno porque sí. 7 El narrador, en pleno campo, hace alarde de su horizonte cultural, de sus lecturas, de sus capacidades de escritor y de pianista inspirado y melancólico, de sujeto fuera de lugar. ${ }^{8}$

La imagen e idea de mujer que se deriva de la "Breve novela campesina” de Silva, contrario a lo que vamos a encontrar en De la Cuadra, es la de un ente ingenuo, de una joven débil y primitiva, encandilada por el prestigio de lo culto y extraño, trágicamente condenada en su tácito anhelo por lograr un presunto e imposible abrazo, como aquel de las estrellas, como aquel con la Venus de Milo que pretendía el modernismo y su máxima figura, Rubén Darío. Ese abrazo no se realiza a ningún nivel. Las diferencias culturales, las diferencias sociales y las diferencias étnicas condenan la relación al fracaso. Y condenan también, por contigüidad, a la realidad que María Jesús representa a una prematura y metafórica desaparición, en tanto se encubre a la misma tras los usos, gustos y adornos de una cultura cosmopolita.

Ese es el imaginario femenino que pareciera querer fomentarse en los lectores de ese entonces y no es otro que el que promulga una cultura dominante, burguesa. Lo paradójico es que esa mujer incidental y "rechazada”, al igual que el referente que ella simboliza,

${ }^{6}$ Los familiarizados con la narrativa de José de la Cuadra (1903-41) recordarán que en Los monos enloquecidos ([1931] 1951), la novela póstuma, inconclusa, del autor guayaquileño, se dan referencias bien parecidas a las que hemos citado de Silva $(O C, 677)$.

${ }^{7}$ Ornamento, arte que se añade al arte y que no ha de confundirse con el adorno, vocablo más general que remite a lo que embellece. Véase el efectivo artículo de James Trilling, "Modernism and The Rejection of Ornament: The Revolution That Never Happened", Common Knowledge (79-110). Silva pareciera querer enmascarar, por no decir borrar, una realidad estética, la de una imaginación primitiva y su correspondiente tradición oral, con otra, letrada, que él presta y traslada de otro lugar y a la cual alude y a la cual nombra casi porque sí, sin verdadera razón de ser, como por puro alarde, como mero adorno, sin más.

${ }^{8}$ El concepto e idea "fuera de lugar" ha sido persuasiva e inteligentemente desarrollado por Roberto Schwarz en su Misplaced Ideas. Essays on Brazilian Culture. Véanse manera particular los primeros cuatro capítulos. 
acabará sobreponiéndose históricamente al orden de lo exquisito y de lo fino. No, no se impondrá como arquetipo auténtico de mujer ecuatoriana, y menos de patrón de belleza a emular, mas sí como cimiente, aunque sólo en germen, de atributos que proponen la invención de una mujer "ecuatoriana”, costeña. Por cierto, la narrativa inmediata oscilará entre el mundo cosmopolita y el referente nativo que Silva tuvo a mano, pero que éste -llevado por sus inclinaciones ideológicas, por su concepción del mundono supo aprovechar ni intervenir: lo descartó y hasta lo ubicó en un grado subalterno.

“DEL MATRIMONIO EN DERECHO CIVIL” Y “LA PROPIEDAD DE LA MUJER”

En el caso de Silva , entonces, no resulta lícito hablar ni de un literal o metafórico coito cultural ni de aculturación o transculturación, conforme elucida esos conceptos Fernando Ortiz en su Contrapunteo cubano del tabaco y el azúcar (136-42). Los dos ámbitos que entran en juego en María Jesús se mantienen aparte, sin un verdadero “contacto” y, como consecuencia, sin evidencia por ningún lado de zonas culturales intermedias o de "macidez", sea afectándose, infectándose, o repercutiendo la una en la otra. ${ }^{9}$ Ello no descarta el hecho de que en el horizonte ecuatoriano de la época se esté gestando una honda contienda por el poder político, económico y cultural. En lo que toca a la mujer, ésta, incluso en los centros urbanos, apenas se manifiesta como ser laboral y menos como presencia a un alto nivel profesional. La lucha por el sufragio y por el acceso a centros de enseñanza superior, no hablar de códigos civiles y penales, apuntan a su condición de subalterna y, por repercusión, a una sociedad fundamentalmente agraria,

\footnotetext{
9 “Zonas de contacto” y “zonas de macidez” son conceptos que manejó De la Cuadra en su ensayo "El arte ecuatoriano del futuro inmediato", publicado en el diario de Guayaquil El Telégrafo, en 1932 y reproducido por Alejandro Guerra Cáceres en Crónica del Río en 1986. De la Cuadra se planteó el asunto de dichos conceptos para referirse específicamente a las luchas sociales y, por extensión, culturales. Dijo: “las clases sociales ... no viven aisladas. Constantemente se interfieren; y, estas situaciones influyen ... trasladando su influencia, por repercusión, desde las que llamaríamos 'zonas de contacto' a las que llamaríamos 'zonas de macidez', es decir, a aquellas donde -por condiciones eventuales o permanentes...-, el espíritu de la clase social soporta instantes de transitoria inanidad o se manifiesta con desviaciones y contradicciones de ideología...” (51). Al menos en dos ocasiones anteriores, el suscrito conjeturó sobre el vocablo macidez sin precisar definitivamente su significado, especialmente porque la palabra no figura en los diccionarios. De entonces a acá, la relectura de La interpretación de los sueños de Sigmund Freud, capítulo II, me ha permitido fijar de dónde recogió el término y la acepción de macidez De la Cuadra. En el libro indicado, Freud describe un sueño suyo del 23-24 de julio de 1895 en que figura una de sus pacientes. $\mathrm{Al}$ auscultar a ésta, Irma, él y sus colegas le descubren una zona de macidez. Se trata de una zona infectada, infiltrada. De la Cuadra usa el término, a su vez, para indicar zonas infiltradas o infectadas ideológicamente y (¿por qué no?) culturalmente. ¿No es eso, acaso, lo que ocurre cuando se da el encuentro / desencuentro de dos culturas y se produce el fenómeno llamado transculturación que Fernando Ortiz y Angel Rama han planteado como fundamental para entender la situación cultural latinoamericana? Si se tiene todo eso en cuenta, conforme se verá oportunamente, se entiende con mayor precisión y latitud la base conceptual, el encuentro de culturas, que organiza buena parte de los escritos literarios del autor guayaquileño. No se olvide que De la Cuadra fue un ávido lector de Freud.
} 
muy a distancia de un capitalismo moderno. ${ }^{10}$ Lo urbano y lo rural, el cosmopolitismo y el nativismo, el feminismo burgués y el socialismo están en el aire. La crisis implícita a la que aluden esas tendencias repercute en la gama de interpretaciones de la mujer que van desde lo tradicional, estilo María Jesús, hasta las vislumbres de una mujer nueva por venir. El nativismo, con no pocos ecos de un realismo social en boga, acabará imponiéndose. En el fondo, ese nativismo o regionalismo constituye una búsqueda de identidad propia, una defensa frente a los excesos de un cosmopolitismo trasplantado, desprovisto de un sentido crítico.

Durante las décadas del veinte y del treinta, sin embargo, la imagen e idea de la mujer que se promueve no sólo procede del agro, sino también de ámbitos urbanos, modernos, donde ronda también de cerca la presencia de la Vanguardia histórica. La producción de José de la Cuadra es ilustrativa tanto respecto a lo urbano como a lo rural. Pablo Palacio (1906-48), a su vez, es el escritor paradigma dentro de la Vanguardia. Leer a esos dos escritores teniendo en cuenta la idea e imagen de la mujer y las relaciones de género que proponen sus obras es algo que ha pasado mayormente inadvertido. Detalle preocupante, especialmente si se tiene presente que en los relatos del uno y el otro abundan los personajes femeninos, vistos en diferentes circunstancias y situaciones. Preocupación más seria aún porque los dos autores meditaron y escribieron sobre relaciones genéricas. En 1927 De la Cuadra presentó su tesis doctoral titulada "Del matrimonio en derecho civil”; y Palacio, en 1932, publicó un sesudo ensayo sobre "La propiedad de la mujer". ${ }^{11}$

No es que estemos proponiendo ni descartando relaciones entre literatura y ensayo o viceversa, mas sí incumbe puntualizar que en los dos escritores, abogados y militantes socialistas ambos, hubo una clara preocupación por lo femenino hasta el punto de que los análisis históricos y jurídicos que realizaron los ubica dentro del debate de los derechos

${ }^{10}$ Lucha vista en términos de derechos impulsados por un socialismo de inspiración marxista. Ello no implica, sin embargo, que el feminismo como tal (al menos el feminismo burgués) sea inexistente en el Ecuador. Al contrario. Recientemente se ha iniciado una recuperación de figuras femeninas que abrieron brecha en su momento en la historia social y política del Ecuador. En 1777, el alegato de mujeres amerindias en contra de la pretendida Numeración de Indias que permitiría ajustar las tasas tributarias. Al nivel individual, destacan Zoila Ugarte de Landívar (1864-1969), Rosa Borja de Icaza (1889-1964) y Matilde Hidalgo (1889-94). Aquélla, declarada feminista, fundó la revista La Mujer (1905) y el Centro Feminista Anticlerical (1930). Hoy por hoy se la considera una pionera del feminismo y del periodismo ecuatoriano. La segunda, escritora respetada, abogó por la educación de la mujer y, en general, por el significado de la misma “como factor importante en el mejoramiento humano”. La carrera de la última es ilustrativa de varias cruzadas: 1913, primera mujer que culmina la enseñanza secundaria; 1921, primera médica del Ecuador, no sin antes haber librado largas batallas contra las autoridades universitarias; 1924, primera votante, el derecho existía desde que se instituyó la Constitución de 1897; 1929, Matilde Hidalgo de Prócel, primera mujer bachiller, médica, concejala y diputada es también la primera en ir a las urnas. En 1957, Carmela Suárez Veintimilla de López es la primera mujer que por elección popular llega al Congreso. En los últimos treinta años, poco más o menos, se proliferan las instituciones con intereses en lo femenino. Así: el Instituto Ecuatoriano de Investigaciones y Capacitación de la Mujer (IECAIM) y la Asociación Femenina Universitaria (AFU). Mucho queda por consolidar.

${ }^{11}$ José de la Cuadra,’Del matrimonio en derecho civil”, tesis doctoral inédita, 1927. Pablo Palacio”, La propiedad de la mujer”, El Día, Quito, 14 de junio, 1932, 1. Entiendo que, con motivo del centenario de su nacimiento, el Archivo Histórico del Guayas va a imprimir el texto de aquél. 
femeninos. De la Cuadra se centró en el Código Civil y el matrimonio; Palacio en la cuestión del adulterio, de la mujer y sus derechos dentro del Código Penal. Ninguno de los dos, sin embargo, tradujo su conocimiento jurídico en un medio para promover una política en favor de la causa femenina, causa con la cual, no obstante, cabe conjeturar, simpatizaban y entendían. A cada uno de esos escritos haremos referencia oportunamente.

ENTRE UNA LITERATURA GALANTE Y UNA DE DENUNCIA Y PROTESTA

"Ventura es de artistas el magnificar metamorfosis de su propio espíritu, sin perder -y fíjase aquí el alto punto de milagro- la alta evidencia de ser ellos mismos, diversos y unos a la par”, anotó De la Cuadra en un artículo sobre Publio Falconí, publicado en Vida Femenina de Montevideo en 1932. En otra ocasión, en "El arte ecuatoriano del futuro inmediato”, artículo publicado en El Telégrafo de Guayaquil, abril-mayo de 1933, De la Cuadra dijo asimismo que "el arte, en sus varias manifestaciones, ha obedecido y obedece en función de efecto, a una orientación clasista.... Consecuencia de la economía en marcha, las clases sociales son de estructuración económica. Y así, pues, el arte, fenómeno social de orientación clasista, viene a ser, en definitiva, fenómeno de orden económico" (respectivamente, reproducciones en Kipus, 14; Crónica del Río, 50).

Esas citas proponen que en lo que respecta a la idea e imagen de la mujer se da una constante en la obra de De la Cuadra que va a cambiar de énfasis de lo que podría llamarse un feminismo burgués, urbano, preocupado por relaciones de pareja y con la institución del matrimonio, hacia una interpretación fundada más bien en inequidades debido a las diferencias entre las clases sociales. Tanto en un caso como en el otro se trata de exponer abusos e inequidades en la situación y circunstancia de la mujer en la sociedad.

Lo dicho no sugiere que De la Cuadra fuera un feminista. Su inclinación pareciera remitir más bien al marxismo entonces en pleno apogeo. Digo pareciera porque al formular ese juicio habría que tener en cuenta que aquél presentó en 1927 su tesis doctoral titulada "Del matrimonio en derecho civil” en la que se constata su familiaridad no sólo con las premisas marxistas que estaban en el aire respecto a la situación y condición de la mujer en cuanto al matrimonio y en la vida social toda, sino también respecto al feminismo, sin reivindicar ni la una ni la otra tendencia respecto a las relaciones entre los sexos. ${ }^{12}$ Dos figuras femeninas que han seguido resonando, y últimamente con más vigencia, aparecen citadas y comentadas en esa tesis presentada a la Universidad de Guayaquil: Ellen K. S. Key (1849-1926) y Aleksandra Kollontai / Alejandra Kolontay (1872-1952). Una y otra han dejado surco en la lucha por los derechos de la mujer. A ambas se remite De la Cuadra para ratificar que "La institución del matrimonio atraviesa [...] una verdadera crisis. Las doctrinas sociales generales, en sus pretensiones hacen constar la de alterar fundamentalmente la institución misma”. Pasa luego De la Cuadra a resumir las ideas de Kollantai, diciendo que:

\footnotetext{
${ }^{12}$ En "El derecho al amor”, cuento incluido en Repisas (1931), se discute la libertad sexual femenina. La perorata de uno de los personajes es vista por el narrador "como biliosa disertación, adecuada para un centro feminista o cosa así”. También se interroga y se exclama: “¿Y las feministas? ¡Esas son las supermujeres!” (OC, 233). Lo citado se explica por sí solo y no exige comentario alguno.
} 


\begin{abstract}
Comienza la autora citada por hacer una crítica de la organización actual de la familia y de sus bases, las cuales son, según ella: A) intereses pecuniarios, cálculos materiales, intereses de economía doméstica en el sentido más estrecho de la palabra, aunque ya no como problema de producción (familia productora de los antiguos regímenes capitalistas); B) la dependencia de la mujer al hombre, fenómeno que poco a poco desaparece por el hecho de que las mujeres trabajan ya; C) la obligación de los padres, fenómeno que desaparece más y más de la familia, porque el Estado y la Sociedad cuidan de la educación de los niños”. Luego de hacer una crítica demoledora de esta familia, anuncia que la nueva sociedad, de tendencia cooperativista, se encargará de las funciones de esta familia volviendo innecesaria su existencia. Anuncia también una nueva moral consecuente. La libertad de las relaciones sexuales sólo tendría, para ambos sexos, la limitación biológica, el profundo sentido del bien de la especie; así, critica la poliviria como perjudicial a la sociedad y critica, menos duramente, la poligamia. Pero no refiere estas opiniones al matrimonio mismo, - que debe de ser de un solo hombre con una sola mujer-; refiriéndose concreta y específicamente a las relaciones generales fuera del vínculo. El divorcio en esta organización, sería ampliamente consentido; estando como están sujetas las uniones a la voluntad de los cónyuges y, sobre todo al interés general del Estado que vigilará perpetuamente porque las relaciones sexuales se produzcan en orden a su conveniencia. (33-34)
\end{abstract}

De la Cuadra prosigue a señalar que "las doctrinas especiales sobre el matrimonio -sin ser de carácter social general- como el feminismo, por ejemplo, contribuyen con lo suyo a hacer más intensa la crisis de la vieja institución que, como dijimos más atrás, ha sostenido la organización de la sociedad humana durante tan largo espacio de tiempo. No han jugado menos papel en la provocación de esta crisis las prédicas de libertismo sexual y la labor en este sentido constante en las obras de la señora Key” ("Del matrimonio en derecho civil”, 34).

Marxismo y feminismo, evidentemente, repercuten en el horizonte cultural ecuatoriano y cualquier interpretación de representación de la mujer en la literatura de la época ha de tener eso en cuenta. En el caso de De la Cuadra habría que recordar un factor más: su evidente conocimiento de la obra de Henrik Ibsen (1828-1906), incluso de obras poco fatigadas del dramaturgo noruego como La fiesta de Solhaug (1856) que halla refundición en "Miedo", un relato que el autor nacido en Guayaquil incluyó entre las "Pequeñas tragedias” de su colección Repisas (1931). Que la problemática femenina le interesó al autor escandinavo es bien sabido. Menos, y vale resaltarlo, que Ibsen refundió en su aludida obra motivos que él recuperó de las antiguas Sagas “familiares” de Islandia, según lo explicó en el prefacio a la segunda edición (1882) del drama en cuestión.

Nos hemos extendido sobre los muchos aspectos anteriores porque importa recalcar que múltiples son las venas que corren en la literatura ecuatoriana de las décadas del veinte y treinta, y que por ende es insuficiente decir que se trata de una visión ¿tradicional? de la mujer vista desde afuera por mucho que reconozcamos que el Ecuador de entonces "no es un país de escritoras” ya que, como bien dice Miguel Donoso Pareja, "son hombres quienes escriben sobre las mujeres, abogando incluso sobre su emancipación”. Que este último es el caso con De la Cuadra y Palacio no cabe duda. Que se trata de una visión "paternalista”, ¿en el sentido de indulgente, solícita o condescendiente? habría que matizarlo más. Que “las mujeres tienen que aprender a hablar por sí mismas”, como reitera 
el mismo Donoso Pareja, seguramente sí (Hoy, Quito, 10 de julio de 1983). Me pregunto, sin embargo, si el hecho de hablar las mujeres por sí mismas las libera de cualquier índole de paternalismo. El debate que se libra aún en la esfera pública, debate entre feministas y no feministas y entre feministas y marxistas, pareciera proponer otra cosa.

Volviendo a De la Cuadra, una lectura de la mayoría de sus relatos en que figuran protagonistas femeninas, hasta 1931 inclusive, sugiere que en su producción se da una galería de mujeres que encajan dentro de varias categorías, galería que va desde lo tradicional hasta la presencia en embrión de una nueva mujer. Paternalismos aparte, figuran en esa galería personajes inspirados, se supone, en una suerte de feminismo burgués, no menos subversivos por ese hecho. En cierto sentido, más de una de las narraciones del autor guayaquileño que la historiografía ecuatoriana ha descartado como frívolas y pertenecientes a una literatura galante o rosa -a una literatura de la sociedad y no sobre la sociedad- exigen una nueva lectura. Esa lectura tendría que reconocer que en el fondo de varios de esos relatos se halla un evidente sentido de crisis por el que atraviesa el carácter y naturaleza de la mujer representada. ¡Que podría adscribirse esa interpretación a la influencia de lecturas, por ejemplo, de Ibsen o a las que tuvo que hacer en preparación para su tesis doctoral sobre "El matrimonio en derecho civil” no es del caso! Sí que en varios de los relatos que podríamos traer a colación se manifiesta una mujer cada vez más consciente de sí, y cada vez más en conflicto con el rol que le había asignado la sociedad. Se trata, vale puntualizarlo, de mujeres de la pequeña burguesía guayaquileña, urbanas y hasta cosmopolitas. Y no podía ser de otra manera. La sociedad interpretada era una controlada y dominada por el poder masculino, sociedad en que apenas la mujer de ciertos medios, y sólo mínimamente, contaba, si acaso, con la educación, el trabajo o la independencia económica para sentar desaveniencias con el orden establecido.

Se trata de mujeres en transición, mujeres oponiéndose a las normas de conducta que les asignaba la sociedad. El número es limitado. La presencia de grilletes, tácitos o explícitos, señalan, sin embargo, una situación de crisis en cuanto a la condición de la mujer en sociedad y a cambios en gestación, a la exigencia de un cambio. Relatos como “Madrecita falsa” (1923), “Incomprensión” (1926), “Aquella carta” y “Castigo” (1931) proponen de diferentes maneras esa crisis de valores. Proponen también que una es la condición de la mujer casada y otra de la soltera. Esta última cuestiona y se rebela, aquélla busca salidas, expone el rol que la sociedad, condicionada por el poder masculino, le ha impuesto. El final de "Aquella carta” remite a la mujer tradicional, sometida a la potestad del marido y al matrimonio sin amor. "Castigo" combina desavenencias matrimoniales, adulterio, violencia y crimen. Este se revela como un acto que entrevera desafío, desahogo, reclamo, rechazo y venganza frente a las amarras sociales que han precipitado la sinsalida trágica. En “Incomprensión” se castigan duramente los celos, el paternalismo y la falta de confianza en la pareja. Idálide, la protagonista, mujer en transición, dueña de horizontes cosmopolitas, a la final no puede aceptar el agravio de la falta de estima a que su ser espiritual, su sensibilidad íntima, personal, es sometido. El rechazo y su venganza en embrión, el adulterio, prorrumpe del hecho de que su marido la ve sólo en función de la tradicional esposa, acatada a las normas de lo que él considera es el buen comportamiento en sociedad. En Idálide, al igual que en las otras protagonistas se presiente el imperativo de una ruptura. Se vislumbra el adiós a la mujer sumisa. Este es el caso de manera especial en "Madrecita falsa". 
Escrito en 1923, De la Cuadra incluyó este relato en El amor que dormía (Guayaquil, 1930), después en La vuelta de la locura (Madrid, 1932) y, por último, lo volvió a reproducir en el número 235 de la revista Semana Gráfica de Guayaquil, correspondiente al 26 de octubre de 1935. Si bien no es de sus más memorables narraciones, no está por demás preguntar el porqué lo hizo reimprimir tantas veces. Ello quizás tenga que ver con el hecho de que "Madrecita falsa”, entre las narraciones de ambiente urbano, burgués, constituye un ejemplo verdaderamente subversivo de comportamiento femenino para la época. Comportamiento obviamente vigente desde 1923 hasta 1935 . Y esa vigencia se la entiende aún más en vista de que la protagonista ilustra el caso de una mujer que decide vivir como piensa antes que acabar viviendo como la sociedad cree que se debe vivir. Se rechaza el qué dirán, se rechaza el matrimonio, se rechazan las convenciones, e implícitamente se propone el advenimiento de la madre soltera. En cierto sentido, este relato presenta una mujer en proceso de emancipación que por medio de sus actos y autosuficiencia acaba fundando el sentido de la maternidad y del matrimonio sobre nuevos puntales, apartados de los grillos y normas tradicionales perpetuados por la sociedad en torno al rol de la mujer. Se trata de una mujer dueña de sí misma quien al ratificar sus deseos ratifica su sentido de libertad y su cuestionamiento del matrimonio y de la institución matrimonial. Además, el sentimiento personal supera al amor por la pareja y a los posibles bienestares que ese lazo conlleva.

La galería de mujeres en la obra de De la Cuadra no se restringe a lo dicho. Varias son las categorías en que encajan. Además de urbanas, casadas, burguesas y solteras, también las hay pobres, rurales, analfabetas. En efecto, el otro gran plano de la presencia de la mujer en la obra del autor guayaquileño remite a situaciones inspiradas en la usurpación que aquélla sufre bajo un sistema económico nada equitativo. La ciudad, y las exigencias que conllevan las migraciones a la urbe, las sacude y las precipita hacia cantidad de vivencias y circunstancias desagradables. En algún caso, “Barraquera”, la misma mujer que fue abusada y violada acaba abusando y violando derechos, estancada en una manera tradicional, capitalista, de ser y de entender el mundo. En otros, "Ruedas", “Olor de cacao" y “Se ha perdido una niña” la ciudad y el sistema económico las reduce a la mendicidad, a la nostalgia y a la servidumbre, a la prostitución. Obvio que De la Cuadra no busca en estos relatos la mujer desarrollando una conciencia de sí, sino a la mujer oprimida que por su misma condición de marginada y abusada expone una situación social alegando corrección. La lucha de clases y la necesidad de una sociedad nueva interesa más que una mujer nueva. Las pretensiones de ésta se subordinan a la denuncia y la protesta por las usurpaciones de una clase sobre la otra. Obvio también que De la Cuadra se fija en la mujer trasplantada del campo a la ciudad, mujer servil quien acaba victimada por el orden social establecido. No sorprende, entonces, que sea en el campo y no en la ciudad propiamente hablando donde encontremos, en lo que toca a la idea e imagen de la mujer, una problemática femenina no del todo común y, quizás, hasta inesperada en términos de su potencial vigencia.

Anteriormente se mencionó a Ibsen y su inspiración en las sagas de antiguo, su reconocimiento de que en esas crónicas familiares había material en abundancia para el tipo de preocupaciones que tenía el noruego en ese entonces. Las relaciones entre hombres, entre mujeres, entre seres humanos que encontró en esos escritos, dijo, 
abastecieron su necesidad de expresión y su anhelo de transcribir ese mundo, de transformarlo en diseños propios. Algo parecido le va a ocurrir a De la Cuadra al entrar más y más en contacto directo, antropológico y etnográfico con la realidad campesina del montuvio. Realidad, vale reiterarlo, que había venido siendo parte de sus vivencias culturales desde hacía mucho tiempo ha, y que incluso Medardo Angel Silva, ya lo dijimos, había identificado alusivamente, sin saber aprovecharlo, como potencial cantera para formular toda una literatura. No es, sin embargo, una tradición escrita, como le ocurrió a Ibsen con la historia y literatura noruegas y con las Sagas islándicas, sino la realidad misma del agro la que va a sacudir la inspiración del autor de Los Sangurimas (1934). El estudiante universitario, urbano, de los años veinte cederá el paso al jurisconsulto de los años treinta. Las experiencias de los libros cederá a las experiencias en la realidad. Una tradición escrita es suplantada por una tradición oral. El profesional se familiariza con las costumbres, con los modos de ser, con las emociones, pensamientos y manera de hablar que determinan el mundo montuvio.

La representación de la mujer que se da en buena parte de su producción literaria será un resultado del sentido de esa experiencia. Esa imagen, reflejo al fin y al cabo, sería de esperar que fuera mayormente de índole tradicional, sometida como aparentemente estaba la mujer en dicho ámbito a un feudalismo capitalista y, consecuentemente, a un dominio de la potestad masculina. Pero, cabe preguntar al respecto, ¿qué se proponía De la Cuadra con la interpretación de los personajes femeninos rurales que creó? ¿Ser fidedigno a esa realidad? ¿Cuestionar ese sistema y, por ende, llamar la atención a la condición de usurpada que vive la mujer en ese horizonte? ¿Reclamar para la mujer una condición de fundadora? ¿De agente del cambio? ¿De receptáculo de mitos, de tabús, de violaciones, de consumo y objetivo erótico? Quizás todo eso y más. Lo cierto es que la cuestión es amplia y se complica y se ahonda. Los matices que la imagen e idea de la mujer representa en la galería de personajes rurales que propone De la Cuadra son múltiples. Importa reducirlos a casos individuales, ilustrativos. Importa, además, indicar que el matrimonio como institución no toca parte en el asunto. No existe en realidad. Retumbará, pero apenas se lo vislumbra como norma futura. Lejos están aquí las mujeres de un feminismo burgués, o de cualquier otra índole. Domina el orden natural.

Antes citamos ejemplos de Los Sangurimas y “Banda de pueblo” para destacar la prevalente manera de ver a la mujer que proponía, en los años treinta, una voz rural masculina, proverbial. El vuelco desde un mundo urbano, privilegiado, hacia una mayor representación del mundo campesino y de las clases desposeídas constituye, en el Ecuador de los años treinta, un cambio radical, un cambio de cultura. Y decir cambio de cultura no es una exageración. De un mundo metropolitano con un horizonte cosmopolita, donde imperan la letra y sus atributos, se pasa a uno mas bien primitivo, tradicional, semifeudal, oral, habitado por montuvios, cholos y amerindios, ámbito en que imperan conceptos culturales que nada o poco tienen que ver con los hábitos que rigen en la ciudad. Mucho menos en lo que toca a la mujer. Así, lo que importa, más allá de esa aludida voz varonil, proverbial, es ver cómo se perfila esa mujer en varias de las narraciones cuya geografía es el agro. La geografía, la oralidad, el estado civil y el orden socio-económico en vigencia parecieran, entonces, tener máxima significancia en la interpretación de la mujer. 
En la relación campo-ciudad hay dos tipos de movimiento. Uno que va de ésta a aquél. Otro que representa lo opuesto. En Los monos enloquecidos (1931 [1951]) las mujeres son seres urbanos que han sido trasplantadas al campo bajo el control del hombre. Se presentan frágiles, sumisas e incapaces. La novela pareciera decir que una cosa es ver la realidad desde afuera y otra conocerla desde adentro. La asfixia del medio acaba en una sensación de miedo y espanto frente al mismo. El ser civilizado es trastornado, ha perdido las capacidades para sobrevivir en un ámbito primitivo. Sucumbe. Lo opuesto, con las debidas excepciones, ocurre cuando una mujer del campo pasa a la ciudad. "Se ha perdido una niña”, “Candado”, “Olor de cacao” y “Barraquera” ilustran el caso. Los tres primeros relatos señalan las consecuencias de dicha migración. El abuso, la usurpación y la pobreza conducen a la servidumbre, a la vida del arrabal y hasta la prostitución. Figura en el fondo una nota de nostalgia por el mundo que dejaron atrás. Cuando esa migración, como en "Barraquera”, resulta exitosa, la mujer se aburguesa, cambia de papeles: de explotada deviene explotadora. La protagonista amerindia de ese relato, proveniente de la serranía ecuatoriana, olvidando sus orígenes y su clase, no hablar de su condición de mujer violada y usurpada, se traduce en el Otro. Todas las mujeres de estas narraciones son parte de una lucha implícita que se libra dentro del sistema socio-económico bajo el cual viven; las circunstancias que les toca vivir, por contigüidad, las traduce a todas ellas en agentes de alegato y denuncia frente a ese sistema.

La mujer del campo -radicada en el campo y configurada por sus múltiples geografías- es la que individualmente interesa más. Esa mujer, desprovista de los ropajes de feminismos burgueses y sin la carga ideológica que conlleva la lucha de clases, es la que va a suministrar una imagen e idea paradigmática de sí y de la manera en que la representa literariamente la perspectiva masculina de un autor ilustrado, al tanto de las propuestas del feminismo y del socialismo. Que De la Cuadra recapacitó a fondo sobre la geografía cultural del agro, y sobre la circunstancia de la mujer en ese ámbito, lo derivamos de $E$ l montuvio ecuatoriano, su ensayo sociológico de 1937, publicado en Buenos Aires. Es de allí de donde reproducimos estos fragmentos sobre el asunto:

[...] las mujeres montuvias ... Son buenas amas de casa, por mucho que no dominen las artes menores domésticas.... Por lo que atañe a las faenas propiamente campesinas, la mujer montuvia, con las exclusiones lógicas, es tan capaz y tan experta como el hombre montuvio. Resulta admirable contemplarla tomar el puesto del varón: desde ordeñar una vaca hasta sembrar arroz con empeque.... La familia montuvia gira en torno de la madre ... en lo afectivo. El impulso a la madre es netamente sentimental, espontáneo.... La familia montuvia constituye una entidad prieta, aislada o casi aislada, que sigue sus propios destinos, sin vincularlos a los de los otros grupos familiares, ... La monogamia y la monoviria son características. Sin embargo, el ayuntamiento marital estable se ejerce casi siempre fuera de la institución civil del matrimonio. En el pasado siglo, o sea cuando el matrimonio era una institución de derecho eclesiástico reconocida por el Estado, la religiosidad acrecía el porcentaje de uniones sacramentales y desterraba la simple convivencia, considerada como un pecado. La actual exigencia legal que da antelación imprescindible al contrato civil, sin el cual no puede efectuarse... el matrimonio religioso, ha traido como consecuencia un aumento del porcentaje de amancebamientos. ... No obstante ello, o quizás por lo mismo, las uniones [fruto de amancebamientos] son más duraderas; y, originándose en la atración sexual amorosa, se van llenando de contenido 
económico ... a lo largo de la vida, y no terminan sino con ésta. La monoviria ... es una constante de la mujer montuvia. La prostitución es rarísima y se produce en virtud de determinantes individuales, no sociales. Casi siempre se manifiesta con escándalo. La prostituta montuvia, cuando lo es de veras, se enorgullece de serlo y recaba una posición de machismo tenoriesco: ella es quien elige. Pero, la mujer montuvia, cuando está en el agro, no busca salidero a su mala situación económica en la prostitución. Sacada de su ambiente, en las ciudades, sí, busca ese salidero. Acude a la prostitución como a una cura de hambre: los burdeles citadinos costeños, especialmente los de Guayaquil, consumen mucha carne montuvia, reclutada máximamente entre domésticas traídas desde las haciendas por sus patrones, prostituidas por éstos y abandonadas después. ... el montuvio... No concibe el mito de la virginidad. Para él no es tabú el incesto. Frente a su mujer adúltera, el marido montuvio se siente más que en su amor, ofendido en su dignidad de macho: reaccionando su venganza preferentemente contra el amante, en quien tratará de castigar la burla de que éste lo ha hecho víctima. No es infrecuente que perdone a la mujer o que, separado de ella, permanezca después indiferente; siempre, por supuesto, que haya logrado la venganza que prosiguiera. (OC, 880-83)

Un somero repaso de las narraciones que transcurren en el agro, ratificaría lo dicho más de una vez sobre El montuvio ecuatoriano, que se trata de una lúcida exposición sociológica, ex-post-facto, del mundo narrativo del autor. Habrá quienes aleguen que lo más perdurable de un escritor de ficciones no son sus ensayos, sino sus obras de la imaginación. Alegarán, y a lo mejor con razón, que es en éstas donde perdura el verdadero espíritu de un autor. Bien puede ser. Estimo, sin embargo, que en el caso de De la Cuadra su pensamiento crítico permite poner en perspectiva el fondo de su mundo inventivo: no a sustituirlo, y tampoco a superarlo, pero sí a entenderlo mejor. Así, la extensa cita anterior propone una serie de apartados que de una forma u otra remite retrospectivamente a interpretaciones literarias. El diálogo literatura-ensayo sociológico, obra de la imaginaciónrealidad, acaba por conferir autoridad a la representación literaria de la mujer, al menos así lo entendió tácitamente el autor nacido en Guayaquil.

La geografía, el ayuntamiento, el amancebamiento, la monoviria, la virginidad como mito, el incesto, el adulterio, la honra y el perdón, la casi ausencia de prostitución, la prostituta y su consiguiente machismo tenoriesco que elige y domina, el impulso afectivo que tira hacia la madre, las capacidades domésticas y de trabajo de la mujer, la atracción de la ciudad y las consecuencias para el ser femenino: todos esos atributos constituyen una figura de mujer que en más de un sentido podría espantar y sorprender, si se matiza bien la complejidad del asunto. Un cotejo de analogías y contrastes con la ya advertida mujer urbana, letrada y cosmopolita, alentada por un feminismo burgués, y con la también ya advertida mujer de clase pobre, subalterna, analfabeta, alentada por el manto de una ideología socialista, quizás revele a la mujer montuvia, en ciertos aspectos, como más liberada y autosuficiente que las otras. Ello no descarta, sin embargo, el profundamente arraigado dominio del padre. La cuestión, y eso debe de quedar claro, es que la representación de la mujer es más compleja de lo que tendenciosamente se podría proponer. No se trata de meramente opinar, sin más, que estamos ante una cultura machista. De la Cuadra cuestionaría esa generalización.

No es factible, pues, entrar a analizar los tantos relatos ilustrativos de este o aquel aspecto que constituye la imagen e idea de la mujer montuvia. Valga, no obstante, un 
repaso de unos cuantos títulos, antes de pasar a centrarnos en Los Sangurimas. Pasto literario hay en "Partición” y "La solterona” para adentrar, respectivamente, en las problemáticas del amor, de la virginidad y de la monoviria en el agro. "El desertor”, "El huésped” y "P’al caso” plantean cuestiones de honor y la situación de la mujer en ese drama. El sometimiento, usurpación y sacrificio de la virginidad a las ansias rijosas de tinterillos aprovechados ocurre en "Honorarios”. El incesto y la representación de la mujer en un contexto rural, aislado, adquiere profunda verosimilitud en "Calor de yunca". La superstición y la mujer poseída y afrodisia se da en "Sangre expiatoria". Conceptos de belleza, tabúes sociales y diferencias étnicas (temas que habría que ver más a fondo en la narrativa ecuatoriana) se dan en "La selva en llamas".

El amor, la pérdida, la melancolía, el culto y el rechazo de la virginidad, el erotismo desbordado, lo mágico, lo mítico de aquí y allá, el conflicto y contacto entre culturas, las leyes de un Estado distante, urbano, y las coordenadas que determinan un mundo semifeudal, primitivo, rural, aislado, el lenguaje jurídico, culto, frente al de "mujeres bravías y lascivas" y el de machos arrechos, la autoridad civil yuxtapuesta a la autoridad mítica, entrega, forzamiento, uso y abuso del varón, bacanales y lujuria, pureza, posesión, entrega, memoria. Todos esos atributos y más se entreveran en el mundo complejo de esa "novelina fugaz” que De la Cuadra tituló “La Tigra”, verdadero cuadro mural sobre el ser y quehacer de esas mujeres independientes del bajío. En el epígrafe que encabeza esta novela corta reza lo siguiente: “Los agentes viajeros y los policías rurales no me dejarán mentir-diré como en el acerto montuvio. Ellos recordarán que en sus correrías por el litoral del Ecuador-¿en Manabí?, ¿en el Guayas?, ¿en Los Ríos?- se alojaron alguna vez en cierta casa-de-tejas habitada por mujeres bravías y lascivas [...] Bien; ésta es la novelina fugaz de esas mujeres" ([sic] OC, 415).

Handelsman ha realizado una lectura "feminista" de "La Tigra" ("Trapped between Civilization and Barbarism, 69-80), concluyendo que aunque la protagonista (Francisca Miranda, alias la Niña Pancha, alias la Tigra):

\begin{abstract}
attempted to appropriate a life in which no man would dominate her, she ended up on the one hand denying her qualities as a compassionate and sensitive woman and on the other hand becoming her own sister's tormentor. According to this reading, however, her conduct is not wholly despicable, since her era was characterized by a clear lack of adequate options for women, be they from the city or the countryside -hence the importance of highlighting the demystification of Prince Charming as the principal means of fulfillment for women. In this sense, despite the excesses that marked her behavior in large part, the great legacy left by the Tigress is her will to act and be selfsufficient in a world that preferred women to remain asleep ... it should be evident that The Tigress contained the seeds of a change in attitude about America and about women.
\end{abstract} (78)

La mayoría de esos juicios son de provecho, persuaden, si bien hubieran resultado más autorizados aún de haber elaborado, quizás, los aspectos alusivos del epígrafe citado en que la base real de la narrativa de De la Cuadra es puesta en perspectiva, de haber tenido más en cuenta, en suma, el pensamiento crítico sobre la experiencia femenina del agro apuntada en El montuvio ecuatoriano, especialmente lo que este texto sociológico 
propone sobre las capacidades propiamente camepesinas, no me refiero a las domésticas, de que es capaz la mujer montuvia. Más aún, a la luz de ese texto ¿cabe pensar en "La Tigra” como una interpretación "alusiva” de la prostituta montuvia que "se enorgullece de serlo y recaba una posición de machismo tenoriesco: ella es quien elige?” ¿Interpretación alusiva o una explicación literaria del cómo y por qué de una prostituta del agro, de sus vivencias, de su razón de ser y proceder? Quizás todo eso. Realidad e imaginación se funden. No es aquí del caso, sin embargo, para forjar esa lectura, ni para formular interpretaciones sobre las motivaciones que conducen a la protagonista hacia ese tipo de conducta. Sí vale insistir en su libertad de comportamiento (en lo que atañe a su sentido: sexual, moral, de género, del pecado, del cuerpo, y de lo femenino, en general), en su descuido y transgresión de reglas sociales de conducta impuestas a la mujer, cualidades sobre las que habría que inquirir más a fondo para fijar hasta qué punto colocan a la Niña Pancha cerca o lejos de adjetivos propuesto por las antes citadas agentes de cambios en favor de la liberación de la mujer: Kolontai y Key, en este caso.

Pero, entendamos, De la Cuadra no está proponiendo una interpretación de la Tigra como un paradigma de la mujer liberada. No obstante, si hace de ella, presunta prostituta montuvia, un ejemplo de transgresión y promiscuidad que por contigüidad cuestiona instituciones como, dígase, el matrimonio, recordándonos, de paso, lo que al respecto propuso Octavio Paz en el “Apéndice” de El laberinto de la soledad. Si parece claro, y esto va a resultar más evidente al examinar Los Sangurimas, y al tener en cuenta, a su vez, el Código Civil o el Código Penal ecuatorianos, que los proyectos feministas que estaban en el aire, al igual que la legislación proveniente de las ciudades, resultaban fuera de lugar, distanciados de la realidad del agro, a pesar de que dichos proyectos, de habérselo propuesto, bien podían haber aprendido de ciertas pautas de comportamiento de mujeres montuvias auto-suficientes, independientes. No de todas.

Los Sangurimas. Novela montuvia ecuatoriana (Madrid, 1934) fue el título original de la obra literaria más acabada que dejó De la Cuadra. Casi todos los atributos que propuso en El montuvio ecuatoriano sobre la mujer ya se habían dado en la representación literaria de la misma que figura en el mundo novelístico, anterior, por cierto, a la explicación sociológica. Esta, hay que reiterarlo, reflexiona la razón de ser de aquélla: relación o enlace entre literatura y realidad que se repetirá en el pensamiento crítico del autor guayaquileño, y cuyas fronteras no es siempre tarea fácil de deslindar.

En todo caso, no es de entrar aquí en la trama de esa obra. Valga sencillamente decir que se trata de una saga familiar, desde su fundación, por una mujer, hasta su apocalipsis, precipitado éste por la agencia directa o indirecta de una mujer también: "una familia montuvia en el pueblo montuvio: un árbol de tronco añoso, de fuertes ramas y hojas campeantes a las cuales, cierta vez, sacudió la tempestad" ([sic] OC, 451). Dentro de ese marco, Los Sangurimas resulta un compendio de la representación de la mujer y de su lugar en el condominio de “La Hondura”, la mítica y apartada hacienda de la familia Sangurima.

Podría pensarse en la representación de la mujer en ese espacio mítico en términos de una suerte de paso dramático que consistiría en tres actos y un epílogo. En el "primero" aparece la fundadora, la madre de Don Nicasio Sangurima. Mujer sin verdadera identidad. Carece de nombre. Es Sangurima y nada más. Mujer que es presencia erótica, deseo aprovechado. Madre soltera. Mujer "fuerte”, natural, protectora de su crío, víctima y 
practicante a la vez de la ley del talión. Prisionera, por ello mismo, de las reglas y costumbres del agro. Mujer mito. Mujer memoria. ¿Malinche? ¿Tránsfuga? Núcleo afectivo. Fin y objetivo del culto de la madre. ¿Mujer pura, santa?

"Mi mama era una santa”. Así hace memoria ño Nicasio de su progenitora. Es de esa "santa” que procede el latifundio semi-feudal que constituye "La Hondura”. Latifundio que es en su momento, a fin de cuentas, producto de una violación, de una alteración en el sistema de relaciones y comportamientos establecidos por la tradición. Alteración que es seducción y violación efectuada por un extraño, el padre gringo de ño Nicasio. Esa alteración, presencia e invasión extranjera, no cambia nada la condición de la mujer. Así, el orden patriarcal que impondrá el hijo de la fundadora en el predio solo se lo entiende en términos de la adhesión de aquélla al ethos del agro, ethos dominado por un machismo conservador que ño Nicasio reitera, perpetúa y expande. Amancebamientos, incestos, venganzas, prepotencias y petulancias parecieran ser el legado de esa madre, en tanto ella no reorienta las costumbres que hereda. Y tampoco tenía por qué hacerlo. Al respecto, sin embargo, sí importa desmitificar su cartel de mujer “fuerte”. ¿En qué sentido lo es? En ninguno, en realidad. Su comportamiento está engrillado en la tradición de aquí y allá. Ella, mujer anónima, se revela autosuficiente, pero asumiendo las leyes del varón, sin más. La semilla que implantó el gringo en el sistema no condujo a nada, a no ser que sea la creación del terrateniente. La presencia de aires extraños solo dejó un vástago intransigente en eso de defender y perpetuar comportamientos esenciales sobre cómo deben ser las cosas respecto a la mujer y a la familia. No es acaso válido pensar que al igual que la mujer, el hombre no nace, sino que se hace. ¿Qué inculcó esa madre para socavar la preeminencia de un patriarcado y de un latifundismo sin límites ${ }^{13}$

¿Acaso De la Cuadra está llamando la atención al hecho de que hay ciertos cultos metafóricos, como el de una fundación histórica o como el de la madre, que importa desmantelar, en vista de que acaban convirtiéndose en cargas que traducen impotente a una cultura en tanto la misma busca una salida o una posibilidad de cambio positivo? Seguramente. Al respecto, el "segundo acto" de la obra es ilustrativo. Junto con el militarismo (y Los Sangurimas parodia los levantamientos y montoneras), el clericalismo (representado en términos igualmente grotescos) y la manipulación de la ley y del orden jurídico (metafóricamente asesinados en la obra) son las relaciones de género (sea con la madre, sea incestuosa, sea el amancebamiento, sea la ambigüedad sexual, sean los alardes de consquista tenoriesca, sea la visión de la hembra como puro animal reproductivo por parte del macho, sea el machismo) las que se constituyen en epítome, en definidoras y catalizadoras ya de la tradición o del cambio.

\footnotetext{
${ }^{13}$ Respecto a este último párrafo, habría que considerar la palabra "gringo" en su más amplio sentido: el de extranjero. Por otro lado, y teniendo eso en cuenta, no es desfachatado pensar que la fundación de "La Hondura", la mítica hacienda en que transcurren los hechos de Los Sangurimas, remite, al menos metafóricamente, al equivalente de la fundación de la nación. En Los monos enloquecidos, De la Cuadra se había expandido en torno al tema, teniendo en cuenta conquistadores y conquistados, la problemática del mestizaje, y, no menos, la cuestión de cómo el terrateniente llegó a constituirse como tal (OC, 622-23). Don Nicasio Sangurima resulta así un equivalente, incluso en lo étnico, de Gustavo Hernández, el protagonista de la novela de 1931, novela que quedó inconclusa, y solo halló luz póstumamente, en 1951.
} 
Debe quedar claro que la representación de la mujer en De la Cuadra se funda en la presencia de múltiples discursos que coinciden en la esfera pública del agro o de la ciudad. "La Tigra” representa un tipo de mujer. La madre de ño Nicasio otra. Igual con el resto de las que habitan en "La Hondura”. Allí, pasando ahora a una suerte de "tercer acto”, se está gestando una mujer que tiene conocimiento del campo, pero que vuelve al mismo interpelada por los gérmenes de una formación ciudadana. Eso ocurre con tres de las nietas del patriarca, llamadas “Las tres Marías” (María Mercedes, María Victoria, María Julia). Mujeres indudablemente atractivas, blancas (añade el narrador). Representan un futuro femenino en embrión. De otro lado, en oposición, está la tradición, personificada en "los Rugeles”, nietos también del patriarca (Pedro, Manuel, Facundo). La coincidencia de esos dos grupos, encuentro y desencuentro de culturas, tendrá consecuencias funestas. Surgen los enredos amorosos y las diferencias de ethos. Ellas insisten en el matrimonio. Ellos, en cambio, en el ayuntamiento sin más, conforme a las rancias costumbres montuvias. "Los Rugeles” ceden, aceptan. Hablan con el padre de ellas.

Páginas atrás citamos ese encuentro (OC, 503-04). Las diferencias culturales en relaciones de género y en actitudes culturales que pone en perspectiva ese diálogo recalca el peso que conlleva el ser mujer en el horizonte montuvio. El padre de las muchachas no accede, se pierde en ambigüedades. Los jóvenes se sienten humillados. Declaran venganza. "Las tres Marías”, entre tanto, no han perdido totalmente su identidad montuvia. La precipitación hacia el acto trágico que "resuelve” el choque entre las zonas opuestas no poco tiene que ver con su estupidez y coquetería. Juegan con la idea de una fuga. Una de ellas, María Victoria, así lo decide y huye con Facundo, el cabecilla de "los Rugeles”. Se emprende una búsqueda. Se constata el hecho bárbaro, la venganza de "los Rugeles”. La escena espantosa que describe ese hecho es de un impacto y truculencia insospechados, analogías podría uno hallar con algún film de Bergman, La virgen primavera, por ejemplo, inspirado en un mundo primitivo, o con alguna propuesta suscrita en alguna tragedia griega, dígase la Antígona de Sófocles, donde hay referencias a buitres y cuerpos humanos desacralizados. Citamos esa escena en extensión porque las implicaciones de la misma remiten a posibles interpretaciones en cuanto a cuestiones genéricas y a la impresión que quizás De la Cuadra quería causar en su lector respecto al barbarismo a que era capaz de llegar un machismo pervertido y perverso, primitivo, auspiciado por un orden patriarcal, caduco y semi-feudal:

La cabalgata se aproximó al sitio donde estaban los gallinazos, espantando a las aves.

Cuando la negra nube de alas se levantó dejó al descubierto un cuerpo desnudo de mujer. Junto al cadáver estaban las ropas enlodadas, manchadas de sangre....

-Es María Victoria. Ese traje llevaba.

... constató el hecho bárbaro.

A la muchacha le habían clavado en el sexo una rama puntona de palo-prieto, en cuya parte superior, para colmo de burla habían atado un travesaño formando una cruz. La cruz de su tumba.

Estaba ahí palpable la venganza de "los Rugeles".

Seguramente Facundo, tras desflorar a la doncella, la entregó al apetito de sus hermanos ... 


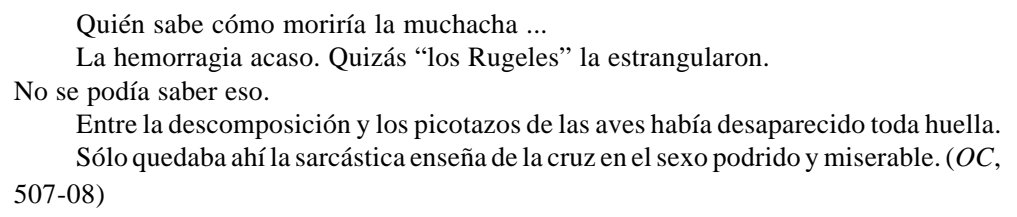

La escena abunda en implicaciones y sugerencias metafóricas: Victoria que es derrota. Falo que es cruz. Falo que usurpa y encadena. Vagina expuesta y violada que propone la completa deshumanización de la mujer. Sexo podrido que niega la fecundidad y desacraliza lo sagrado al burlarse de la mujer como ser reproductivo. Fecundidad que es bárbaramente pisoteada y sangrada, que se constituye en una amenaza al orden patriarcal, semi-feudal, herencia colonial. Mujer que se convierte en desperdicio, que se la expone carcomida por los gallinazos simbólicos de una cultura que la picotea y anula, que la desflora, consume y abandona a portar el sarcasmo de una cruz incrustada, atentado bestial y asqueroso contra el más íntimo y sagrado eje de lo que constituye al ser femenino. Cruz y mujer. Sexo y machismo. Zonas de choque. Ethos y conflictos. Ciudad y campo. Derecho civil y derecho natural. Matrimonio y amancebamiento. Iglesia y Estado. El incesto y sus consecuencias.

De todo lo anterior participa y a todo eso alude la escena citada. De la Cuadra intentó seguramente que se deduzca de ella, por analogía y como suerte de “epílogo”, el estado corrupto del orden político y social en vigencia; y también, y más, dentro del presente propósito, la horrenda relación que existía entre los géneros. Así, la inmensa importancia estructural que la mujer juega en Los Sangurimas no puede menos que denunciar la usurpación de los derechos de la mujer dentro del orden representado. Orden que no es otro que el patriarcado, tema central de la obra. Patriarcado que es expuesto, ya se lo dijo, como caduco y bárbaro, que trasciende lo literario, que involucra toda la historia y cultura del país, cultura que privilegia al hombre sobre la mujer. Patriarcado que remite a una circunstancia incestuosa, dañina, cuyo último resultado es la explosión que se da en el orden literario y que por contigüidad no puede menos de remitir al orden socio-político e histórico también.

Un detalle no ha sido lo suficientemente subrayado en la lectura de la masacre de María Victoria, y ello tiene que ver con las diferencias que se producen en el agro en cuanto a la cuestión matrimonio y amancebamiento. Al resaltar el asunto no se trata de favorecer una inclinación en favor de la otra, sí en proponer que al analizar la representación de la mujer en la narrativa ecuatoriana es sumamente importante tener en cuenta la perspectiva desde la cual se la juzga. Es insuficiente hablar de retrasos en este o aquel orden sin tener en cuenta que en más de una ocasión caemos víctimas de nuestra propia ideología y olvidamos que la mayor diferencia que existe entre los seres humanos es la cultura. Así, la geografía cultural que configura a la mujer montuvia, ni la vara con la cual se mide su situación, no puede ser la misma que la que configura a su hermana de la ciudad y de una clase privilegiada, póngase por caso.

Es por eso que resulta ilustrativo cerrar esta parte del recorrido que venimos haciendo con una referencia al matrimonio y al adulterio, según lo planteó Pablo Palacio en "La 
propiedad de la mujer”, artículo publicado en el periódico El Día de Quito en 1932 (1): “Cualquier día de éstos va a estallar la gran revolución de las mujeres contra el artículo 24 del Código Penal, que autoriza al marido para matar a la mujer que no le ama, ahora que no se conquista a la mujer por la fuerza, sino con un bastón y con una hermosa caída de ojos en una tarde primaveral”.

La imagen e idea de la mujer que se da en De la Cuadra apunta al potencial de una explosión revolucionaria realizada por mujeres. Si esa revolución remitía al orden político y social es menos importante que la revolución cultural en favor de la mujer que se deduce de más de una de sus narraciones. Está claro, también, que De la Cuadra lleva el discurso sobre la mujer a distancias que mucho distan de lo que proponía Silva. Importa recapacitar asimismo que el Codigo Penal ecuatoriano citado por Palacio -ya no vigente, claro- se refiere al adulterio dentro del matrimonio, pero ¿qué de la mujer montuvia que no se sometía a dicha legislación? ¿Qué de las diferentes clases sociales? ¿Qué de la legislación de la urbe imponiéndose en el campesinado y en las clases desposeídas?

Ha de quedar claro, pues, que varios son los discursos que cofluyen y se contradicen en la narrativa ecuatoriana en lo que respecta a la representación literaria de la mujer. Ya hemos visto las varias problemáticas que plantean Silva y De la Cuadra. Palacio llevará el asunto por la ruta de la parodia. Hará pausa, además, en las desavenencias de los diferentes órdenes o desórdenes, según la perspectiva, que constituyen el virus de la opinión pública afectando a la mujer. Más tarde, Adalberto Ortiz, en su Juyungo: historia de un negro, una isla y otros negros (1943), recapacitará con sensibilidad sobre el concepto y el fondo étnico que crea "el mito de belleza femenino”, y cómo afecta ese mito la relación entre géneros. Finalmente, hay harto pasto para elaborar una larga discusión, fuera de los alcances de espacio aquí posibles, sobre la literatura narrada por mujeres que se manifiesta con dinámica y vigor desde la década del ochenta, por ejemplo. Pienso en Alicia Yánez Cossío, Eugenia Viteri, Gilda Holst, Sonia Manzano, Liliana Miraglia, Carolina Andrade, Aminta Buenaño, Yanna Hadatty, Marcela Vintimilla, entre tantas más. Cualquiera de esos recorridos, sin embargo, tiene que tener presente la tradición literaria, en cuanto a la idea e imagen de la mujer, que aquí hemos comenzado a ilustrar, dando preferencia a De la Cuadra, cuyo aniversario de su nacimiento se celebra precisamente este año.

BiBLIOGRAFÍA

Ansaldo Cecilia. Cuentan las mujeres: antología de narradoras ecuatorianas. Quito: Planeta, 2001.

Beauvoir, Simone de. Le Deuxième Sexe. Paris: Gallimard, 1949.

Castro-Klaren, Karen, ed. Narrativa femenina en América Latina. Prácticas y perspectivas teóricas / Latin American Women's Narrative; Practices and Theoretical Perspectivas. Madrid/Frankfurt: Iberoamericana/Vervuert, 2003.

Cuadra, José de la. Obras Completas de José de la Cuadra. Alfredo Pareja, prologuista. Jorge E. Adoum, recopilación, ordenación y notas. Quito: Casa de la Cultura Ecuatoriana, 1958.

“Del matrimonio en derecho civil”, tesis doctoral inédita. Universidad de Guayaquil, 1927. 
“Poemas ecuatorianos. Publio Falconí. (Prólogo a un libro)”. Vida Femenina 152 (Montevideo, 1932). Reproducido en Kipus. Revista Andina de Letras 4 (Quito, 1995-96): 149.

"El arte ecuatoriano del futuro inmediato”. El Telégrafo, Guayaquil, enero 21,23,27, 1932. Reproducido por Alejandro Guerra Cáceres en Crónica del Río. 1 (Guayaquil, 1986): 50-55, y próximo a aparecer también en Kipus. Revista Andina de Letras. 16 (Quito: 2004).

Donoso Pareja, Miguel. Antología de narradoras ecuatorianas. Quito: Libresa, 1997.

“La mujer como narradora”. Hoy (revista). Quito, domingo 10 de julio, 1983.

Eagleton, Terry. The Idea of Culture. Oxford: Blackwell Publisherss, 2000.

Farnsworth, Beatrice. Alexandra Kollontai: Socialism, Feminism and the Bolshvik Revolution. Standford, CA: Standford University Press, 1980.

Franco, Jean. Plotting Women. Gender and Representation in Mexico. New York: 1989. Freud, Sigmund. La interpretación de los sueños [1900]. Buenos Aires: Ediciones Orbis, 1988.

Gilligan, Carol. In a Different Voice. 1982. Cambridge: Harvard, 1993.

Handelsman, Michael. "Trapped between Civilization and Barbarism: An Analysis of 'The Tigress’of José de la Cuadra”. Latin American Perspectives 24/4 (July 1997): 69-80.

"Mujeres del Ecuador dentro y fuera del burdel: Dos novelas y sus contextos de lucha y reinvindicación”. Letras Femeninas XXIII/1-2 (1997).

“Baldomera y la tra(i)ción del orden patriarcal”. Inti 40/41 (1994-1995):194-205.

“Una doble y única lectura de ‘La doble y única mujer’ de Pablo Palacio”. Chasqui 2 (1995): 3-23.

Diez escritoras ecuatorianas y sus cuentos. Guayaquil: Casa de la Cultura Ecuatoriana, Núcleo del Guayas, 1982.

Amazonas y artistas: un studio de la prosa de la mujer ecuatoriana. Guayaquil: Casa de la Cultura Núcleo del Guayas, 1978.

Ibsen, Henrik. The Feast at Solbough. The Collected Works of Henrik Ibsen Vol. 1. William Archer, ed. W. Archer \& Mary Morrison, trads. New York: Charles Scribners and Sons: 1906-1912.

Key, Ellen K. S. Love and Ethics. New York: B. W. Huebsch [c. 1911].

López de Martínez, Adelaida y Gloria Da Cunha-Giabbi. Narradoras ecuatorianas de hoy. San Juan: Editorial de la Universidad de Puerto Rico, 2000.

MacKinnon, Catharine A. Toward a Feminist Theory of the State. Cambridge: Harvard, 1989.

Mata, G. humberto. Dolores Veintimilla, asesinada. Cuenca: Casa de la Cultura Ecuatoriana. Núcleo del Azuay, 1976.

Ortiz, Fernando. Contrapunteo cubano del tabaco y el azúcar. Prólogo de Herminio Portell Vilá. Introducción de Bronislaw Malinowski. La Habana: J. Montero, 1940.

Palacio, Pablo. “La propiedad de la mujer”. El Día. Quito, 14 de junio 1932, 1.

Pareja Diezcanseco. Historia del Ecuador. Quito: Editorial Colón, 1962.

Reyes, Oscar Efrén. Breve historia del Ecuador. Quito: “Fray Jodoco Ricke”, 1960. 
Schwarz, Roberto. Misplaced Ideas. Essays on Brazilian Culture. John Gledson, editor. New York: Verso, 1992.

Silva, Medardo Angel. María Jesús. Breve novela campesina. [1919]. Guayaquil: Casa de la Cultura Ecuatoriana, Núcleo del Guayas, 1965.

Trilling, James. "Modernism and the Rejection of Ornament: The Revolution That Never Happened”. Common Knowledge. 3/2 (1994): 79-110.

Wolf, Naomi. The Beauty Myth. How Images of Beauty Are Used Against Women [1991]. New York: Morrow, 2002. 